\title{
EDITORIAL
}

\section{The News from Baton Rouge}

The past few years have flown by, and 2006 was particularly busy for us. Seed Science Research has a new publisher, Cambridge University Press, and all of us on the production team have been at work getting settled and making new friends. The Journal continues to enjoy the support and efforts of Ms Katy Christomanu and Dr Linda Antoniw, who have migrated along with the scientific staff. We welcome our new associations with Ms Sue Tuck and Ms Karen Neylon at the press. Ms Neylon is working with us to implement an online submission and manuscript tracking system, which will enhance communications among authors, editors and reviewers. We hope to have this service up and running in early 2007.

With the arrival of the New Year comes a change to the Editorial Board. Dr Kent Bradford is retiring as Associate Editor to devote more time to administrative duties at the Davis campus. All of us thank Dr Bradford for his thorough, careful attention to the scientific and editorial quality of the papers under his jurisdiction; he will remain a member of our distinguished Editorial Board. Our new Associate Editor is Dr William Finch-Savage, Warwick HRI, Warwick University. Dr Finch-Savage has distinguished himself in many areas of seed biology, and we look forward to tapping his broad expertise.

In 2006, the Journal further refocused its Editorial Board to reflect the changes in seed biology and the subjects addressed in manuscript submissions (physiological ecology, seed conservation and molecular biology) over the past few years. Joining the Board in 2006 were Drs Phil Allen (Brigham Young University), Roberto Benech-Arnold (University of Buenos Aires), Gerhard Leubner-Metzger (Albert-Ludwigs-University), Hiroyuki Nonogaki (Oregon State University), Hugh Pritchard (Royal Botanic Gardens) and Peter Toorop (Royal Botanic Gardens).

Retiring from the Editorial Board were Drs Carl Leopold, Bryan McKersie, Alfred Mayer, Trevor Wang, Kay Walker-Simmons and Geoffrey Fincher. Many of these individuals were charter or long-term members of the Board. We thank them all for their many years of dedicated service. I would particularly like to thank Drs Mayer and Leopold for their wise counsel regarding my own career, as well as matters related to the Journal. We also mourn the loss of Dr Daphne Osborne who passed away this year; she is irreplaceable.

On behalf of the Cambridge University Press staff, the editors, and the Editorial Board, I thank you for your continued support of Seed Science Research. To all of our readers, and especially to our contributing authors, may 2007 be a healthy and scientifically productive year.

P.S. Mr Cabi remains Mr Cabi - his choice!

Marc Alan Cohn, Editor 